\title{
PENERAPAN METODE ROLE PLAYING UNTUK MENINGKATKAN PEMAHAMAN KONSEP MENGHARGAI KERAGAMAN SUKU BANGSA DAN BUDAYA DI INDONESIA PADA PEMBELAJARAN IPS KELAS V SDN CIJATI
}

\author{
Rahma Intan Talitha, M.Pd ${ }^{1}$ \\ Tiara Cempakasari, S.Pd. ${ }^{2}$ \\ Dosen STKIP Subang ${ }^{1}$ \\ Guru SDN Nangela ${ }^{2}$
}

\begin{abstract}
This study aims to improve understanding of the concept of students in respect of material diversity of tribes and cultures in Indonesia in class V SDN Cijati by applying Role Playing. Based on the lack of understanding of students during the learning takes place so that the study of students is less satisfactory. This study uses a Class Action Research (PTK) with system cycle of planning, implementation, observation and reflection. This research was conducted in two cycles of the techniques used in this study is a technique tests, questionnaires and observations. Assessment Rubric RPP RPP using the first cycle has a percentage of $95 \%$ and cycle II has pesentase 100\% results. Observation sheet IPS implementation of learning by using role playing in the first cycle has pesentase 96.3\% and cycle II has pesentase $100 \%$ results. The results of post-test students who complete the first cycle has a percentage of $70 \%$, while incomplete $30 \%$, while the post-test results of students in the second cycle is finished to have a percentage of $100 \%$. The result of understanding the concept of learners who complete the first cycle has pesentase $87 \%$, while the result of understanding the concept of the second cycle which has pesentase 100\% complete. Application of the method Role Playing very supportive towards the understanding of the concept of cherishing diversity of tribes and cultures in Indonesia, especially in primary schools Cijati. This is due to the application of methods Role Playing educators must be more active in learning, can accept ethnic and cultural diversity, as well as to develop social skills.
\end{abstract}

Keywords: Methods Role Playing, understanding concepts, Valuing Diversity

Ethnicity and Culture in Indonesia

\begin{abstract}
ABSTRAK
Penelitian ini betujuan untuk meningkatkan pemahaman konsep peseerta didik pada materi menghargai keragaman suku bangsa dan budaya di Indonesia di kelas V SDN Cijati dengan menerapkan metode Role Playing. Didasari dengan kurangnya pemahaman peserta didik selama pembelajaran berlangsung sehingga
\end{abstract}




\section{Didaktik : J urnal Pendidikan Guru Sekolah Dasar, ISSN : 2477-5673 \\ Sekolah Tinggi Keguruan dan IImu Pendidikan Subang \\ Volume I Nomor 2, J uli 2016}

hasil belajar peserta didik kurang memuaskan. Penelitian ini menggunakan metode Penelitian Tindakan Kelas (PTK) dengan sistem siklus yang terdiri dari perencanaan, pelaksanaan, observasi dan refleksi. Penelitian ini dilakukan dalam 2 siklus tekhnik yang digunakan pada penelitian ini adalah tekhnik tes, angket dan observasi. Penilaian RPP dengan menggunakan Rubrik RPP pada siklus I memiliki persentase 95\% dan siklus II memiliki hasil pesentase 100\%. Lembar observasi pelaksanaan pembelajaran IPS dengan menggunakan metode Role Playing pada siklus I memiliki pesentase $96,3 \%$ dan siklus II memiliki hasil pesentase $100 \%$. Hasil post-tes peserta didik pada siklus I yang tuntas memiliki persentase sebesar $70 \%$ sedangkan yang tidak tuntas $30 \%$, sedangkan hasil post-tes peserta didik pada siklus II yang tuntas memiliki persentase sebesar $100 \%$. Hasil pemahaman konsep peserta didik pada siklus I yang tuntas memiliki pesentase $87 \%$, sedangkan hasil pemahaman konsep pada siklus II yang tuntas memiliki pesentase $100 \%$. Penerapan metode Role Playing sangat menunjang terhadap pemahaman konsep menghargai keragaman suku bangsa dan budaya di Indonesia khususnya di SD Negeri Cijati. Hal ini disebabkan dalam penerapan metode Role Playing pendidik dituntut untuk lebih aktif dalam pembelajaran, dapat menerima keragaman suku bangsa dan budaya, serta dapat mengembangkan keterampilan sosial.

Kata Kunci : Metode Role Playing, Pemahaman konsep, Menghargai Keragaman Suku Bangsa dan Budaya di Indonesia

\section{PENDAHULUAN}

Mata pelajaran IPS merupakan salah satu mata pelajaran yang diberikan di Sekolah Dasar yang mengkaji seperangkat peristiwa, fakta, konsep, dan generalisasi yang berkaitan dengan masalah-masalah sosial. Mata pelajaran IPS juga mencakup pada materi geografi, sejarah, sosiologi, dan ekonomi. Melalui mata pelajaran IPS, anak diarahkan untuk dapat menjadi warga negara Indonesia yang demokratis, bertanggung jawab, bermanfaat bagi bangsa dan negara serta menjadi warga dunia yang cinta damai. Ruang lingkup dalam mata pelajaran IPS di SD meliputi hal-hal yang berkaitan dengan (a) manusia, tempat, lingkungan, (b) waktu, keberlanjutan, dan perubahan (c) sistem sosial dan budaya, (d) perilaku ekonomi dan kesejahteraan.
Tujuan pembelajaran IPS yang tertera pada Kurikulum Tingkat Satuan Pendidikan (KTSP) 2006, bahwa mata pelajaran IPS bertujuan agar peserta didik memiliki kemampuan sebagai berikut :

1. Mengenal konsep-konsep yang berkaitan dengan kehidupan masyarakat dan lingkungannya

2. Memiliki kemampuan dasar untuk berpikir logis dan kritis, rasa ingin tahu, menemukan, memecahkan masalah, dan keterampilan dalam kehidupan sosial

3. Memiliki komitmen dan kesadaran terhadap nilai-nilai sosial dan kemanusiaan

4. Memiliki kemampuan berkomunikasi, bekerjasama, dan berkompetensi dalam masyarakat yang majemuk, di tingkat lokal, nasional, dan global.

Tujuan-tujuan pembelajaran menurut para ahli di atas maka dapat 


\section{Didaktik : J urnal Pendidikan Guru Sekolah Dasar, ISSN : 2477-5673 \\ Sekolah Tinggi Keguruan dan IImu Pendidikan Subang \\ Volume I Nomor 2, J uli 2016}

disimpulkan bahwa tujuan pembelajaran IPS adalah mencakup pada tiga aspek yaitu kognitif, afektif dan psikomotor yang secara keseluruhan bertujuan untuk membina, mendorong, dan mengembangkan pengetahuan dan pemahaman peserta didik sehingga dapat mengubah perilaku-perilaku yang baik dan menjadi warga negara yang bertanggung jawab.

Karakteristik pembelajaran IPS ini mengutamakan hal-hal, arti dan penghayatan terhadap lingkungan sosial yang fakta atau real untuk menelaah suatu masalah-masalah kehidupan bermasyarakat sesuai pengalaman permasalahan di kehidupan sehari-harinya baik berupa perbedaan pendapat, kebutuhan ekonomi, budaya, dan lain-lain. Selain itu, masalah pembelajaran IPS ini juga bersifat meluas atau komprehensif, sehingga dibutuhkan suatu pemikiran yang analitis, rasional, dan kritis.

Karakteristik pembelajaran IPS merupakan teori bagaimana membina kecerdasan sosial yang mampu berpikir kritis, kreatif, inovatif, berwatak dan berkepribadian luhur, bersikap ilmiah dalam cara memandang, menganalisa serta menelaah kehidupan nyata yang dihadapinya. Oleh karena itu, para pendidik dituntut untuk mampu merangsang dan merencanakan pembelajaran IPS sedemikian rupa melalui pemahaman konsep dengan memperhatikan prinsip dan karakteristik IPS itu sendiri sehingga tujuan pembelajaran IPS dapat tercapai.

Berdasarkan uraian di atas, pemahaman konsep menjadi sangat penting untuk diteliti dan ditingkatkan. Hal ini sesuai dengan pernyataan tujuan KTSP point pertama yakni mengenal konsep-konsep yang berkaitan dengan kehidupan masyarakat dan lingkungannya. Konsep tersebut perlu di pelajari dan diajarkan secara horizontal oleh peserta didik. Untuk memahami suatu pemahaman konsep, terlebih dahulu harus di kaji tentang konsep, pemahaman, dan pemahaman konsep.

Konsep yang di kaji dalam mata pelajaran IPS di SD meliputi hal-hal yang berkaitan dengan manusia, gunung, lautan, daratan, rumah, negara, barang konsumsi, pakaian, pabrik, dan sebagainya. Menurut Ernawati (2003) mengemukakan bahwa yang dimaksud dengan pemahaman adalah kemampuan menangkap pengertian-pengertian seperti mampu mengungkapkan suatu materi yang disajikan dalam bentuk lain yang dapat dipahami, mampu memberikan interpretasi dan mampu mengklasifikasikannya. Sebagaimana diungkapkan oleh Suharsimi, beliau menyatakan bahwa:

Pemahaman (comprehension) adalah bagaimana

seorang mempertahankan, membedakan, menduga (estimates), menerangkan, memperluas, menyimpulkan, menggeneralisasikan, memberikan contoh, menuliskan kembali, dan memperkirakan.

Dengan pemahaman, siswa diminta untuk membuktikan bahwa ia memahami hubungan yang sederhana di antara fakta - fakta atau konsep.

Berdasarkan teori-teori di atas maka dapat disimpulkan bahwa pemahaman adalah kemampuan seseorang untuk mengungkapkan suatu kesimpulan dengan bahasa 


\section{Didaktik : J urnal Pendidikan Guru Sekolah Dasar, ISSN : 2477-5673 \\ Sekolah Tinggi Keguruan dan IImu Pendidikan Subang Volume I Nomor 2, J uli 2016}

sendiri sesuai dengan apa yang diketahuinya melalui pembuktian konsep. Menurut Patria (2007), beliau mengemukakan pendapat bahwa yang dimaksud pemahaman konsep adalah : Kemampuan siswa yang berupa penguasaan sejumlah materi pelajaran, dimana siswa tidak sekedar mengetahui atau mengingat sejumlah konsep yang dipelajari, tetapi mampu mengungkapkan kembali dalam bentuk lain yang mudah dimengerti, memberikan interprestasi data dan mampu mengaplikasikan konsep yang sesuai dengan struktur kognitif yang dimilikinya.

Berdasarkan teori di atas, peneliti dapat menarik kesimpulan bahwa pemahaman konsep merupakan kemampuan seseorang untuk menguasai dan mengungkapkan kembali materi-materi pelajaran dengan bahasa sendiri sesuai dengan apa yang diketahuinya dengan memberikan atau mengaplikasikan suatu materi tersebut secara terstruktur. Jadi pada dasarnya peserta didik tidak hanya ditekankan kepada suatu hapalan saja, namun peserta didik juga harus memahami apa yang telah disampaikan pendidik baik di dalam kelas maupun di luar kelas.

Berdasarkan fakta-fakta dari pengamatan awal proses pembelajaran IPS di kelas $\mathrm{V}$ SDN Cijati di Kp. Cijati Desa Jatimekar Kec. Cipeundeuy Kab. Bandung Barat bahwa pembelajaran IPS harus banyak mengembangkan konsep kehidupan sosial sehingga pemahaman konsep peserta didik terhadap pembelajaran IPS terutama tentang menghargai keragaman suku bangsa dan budaya di Indonesia akan lebih cepat tercapai. Dengan demikian, berbagai kesulitan peserta didik dalam pembelajaran IPS khususnya tentang menghargai keragaman suku bangsa dan budaya di Indonesia harus di atasi oleh pendidik yakni mengembangkan sumber belajar yang sesuai dengan materi, salah satunya adalah penerapan metode Role Playing. Sehingga dari pengamatan di atas sesuai dengan fakta dapat diidentifikasikan masalah-masalah yang dihadapi antara lain :

1. Kurangnya kemampuan peserta didik untuk menyatakan ulang mengenai menghargai keragaman suku bangsa dan budaya di Indonesia

2. Kurangnya kemampuan peserta didik untuk memberikan contohcontoh konkrit tentang menghargai keragaman suku bangsa dan budaya di Indonesia

3. Kurangnya kemampuan peserta didik untuk mengaplikasikan menghargai keragaman suku bangsa dan budaya di Indonesia

4. Rendahnya hasil evaluasi belajar peserta didik pada mata pelajaran IPS

Peneliti telah mengamati bahwa masalah-masalah di atas disebabkan karena beberapa hal, salah satunya dampak dari pendidik yang kurang memiliki pegangan PAIKEM (Pembelajaran Aktif, Inovatif, Kreatif, Efektif dan Menyenangkan), para pendidik kurang menguasai IT (IImu Teknologi) kecuali pendidik honorer, kurangnya kelengkapan media pembelajaran yang dibutuhkan, kebiasaan para pendidik selalu menggunakan metode ceramah, sehingga pada proses pembelajarannya kebanyakan peserta didik tidak terfokus pada penjelasan materi, peserta didik merasa bosan di dalam kelas, 


\section{Didaktik : J urnal Pendidikan Guru Sekolah Dasar, ISSN : 2477-5673 \\ Sekolah Tinggi Keguruan dan IImu Pendidikan Subang \\ Volume I Nomor 2, J uli 2016}

membuat peserta didik menjadi ribut dan tidak nyaman, serta mengganggu atau jail pada temannya yang sedang konsentrasi belajar.

Jika proses pembelajaran IPS ini tidak diperbaiki, maka pembelajaran IPS akan monoton membosankan, peserta didik akan memperoleh pendidikan yang kurang maksimal, tidak bermutu dan kurang bermakna sehingga pada pemahaman konsep pun kurang berkembang termasuk kurang menghargai keanekaragaman suku bangsa dan budaya.

Perlu kita ketahui bahwa tidak ada satu pun metode pengajaran yang paling baik dan sempurna, metode yang paling baik itu adalah metode yang cocok, relevan dengan materi, dan sesuai dengan tujuan pembelajaran. Sehubungan dengan materi tentang menghargai keragaman suku bangsa dan budaya di Indonesia, maka saya memilih metode yang tepat untuk materi tersebut yaitu dengan metode Role Playing.

Ginnot (Eka, 2008) menegaskan bahwa Role Playing merupakan seperangkat prosedur yang digunakan untuk melakukan konseling dengan anak melalui penggunaan secara sistematis dari metode bermain, permainan, dan alat permainan. Sedangkan menurut Van Fleet (2001) menyatakan Role Playing merupakan intervensi yang dikembangkan yang berkaitan dengan penggunaan sistematis dari metode bermain oleh seorang konselor untuk membawa peningkatan dalam kemampuan peserta didik sampai penampilan yang optimal di sekolah.
Berdasarkan kenyataan dan permasalahan di atas, mendorong peneliti untuk mengadakan sebuah penelitian dalam rangka meningkatkan pemahaman konsep peserta didik pada mata pelajaran IPS dalam penelitian yang berjudul "Penerapan Metode Role Playing untuk Meningkatkan Pemahaman Konsep Menghargai Keragaman Suku Bangsa dan Budaya di Indonesia pada Pembelajaran IPS Kelas V SD"

\section{DASAR PEMIKIRAN}

\section{Pembelajaran IPS}

Istilah IImu Pengetahuan Sosial (IPS) secara resmi mulai di pergunakan di Indonesia sejak tahun 1975, IPS merupakan nama mata pelajaran di tingkat sekolah dasar, menegah dan atas, serta nama program studi di perguruan tinggi yang identik dengan istilah "Social Studies". Nama IPS lebih di kenal dengan Social Studies di negara lain itu merupakan istilah hasil kesepakatan dari para ahli dan pakar kita di Indonesia.

Sistrunk Masson (Sapriya, 2009) mengartikan IPS sebagai suatu pengajaran yang membimbing para pemuda-pemudi ke arah menjadi warga negara yang cerdas, hidup fungsional, efektif, produktif, dan berguna. Sedangkan menurut James A. Banks (1990) dalam bukunya Teaching Strategies for the Social Studies (Sapriya, 2007) memberikan definisi bahwa :

Social Studies adalah bagian dari kurikulum sekolah dasar dan menengah yang mempunyai tanggung jawab pokok membantu para siswa untuk mengembangkan pengetahuan, keterampilan, 


\section{Didaktik : J urnal Pendidikan Guru Sekolah Dasar, ISSN : 2477-5673 \\ Sekolah Tinggi Keguruan dan IImu Pendidikan Subang \\ Volume I Nomor 2, J uli 2016}

sikap dan nilai yang diperlukan dalam kehidupan bernegara di lingkungan masyarakat.

Berkenaan dengan ilmu sosial,
Norma Mackenzie
mengemukakan bahwa ilmu sosial
adalah semua bidang ilmu yang
berkenaan dengan manusia dalam
konteks sosialnya atau dengan kata
lain adalah semua bidang yang
mempelajari manusia sebagai
anggota masyarakat.

Adapun teori lain yaitu menurut Charles R. Keller (Sapriya, 2009) mengatakan bahwa:

IPS adalah sebagai suatu paduan daripada sejumlah ilmu-ilmu sosial dan ilmu lainnya yang tidak terikat oleh ketentuan disiplin/struktur ilmu tertentu melainkan bertautan dengan kegiatan-kegiatan pendidikan yang berencana dan sistematis untuk kepentingan program pengajaran sekolah dengan tujuan memperbaiki, mengembangkan dan memajukan hubungan-hubungan kemanusiaankemasyarakatan.

\section{Karakteristik Peserta Didik}

Karakteristik awal katanya berasal dari kata karakter yaitu sifat-sifat kejiwaan, ahlak atau budi pekerti yang membedakan seseorang dengan orang lain, tabiat, watak, berubah menjadi karakteristik. Sedangkan menurut kamus Bahasa Indonesia bahwa karakteristik adalah mempunyai sifat khas sesuai dengan perwatakan tertentu.

Memahami karakteristik kepribadian peserta didik tidaklah mudah. Sehingga antara pendidik dengan peserta didik sama-sama belajar. Dari proses belajar tersebut, banyak pendapat-pendapat atau hasil penelitian tentang macam-macam kepribadian peserta didik yang bertujuan agar terjadi kesinambungan antara satu dengan yang lainnya. Jika dalam kehidupan atau ruang lingkup pendidikan, salah satunya dapat bertujuan untuk memperlancar proses pembelajaran agar sasaran dan ilmu yang disampaikan dapat maksimal saat diterima masingmasing peserta didik. Sehingga dapat dikatakan bahwa memahami kepribadian peserta dapat dianggap modal atau langkah awal para pendidik sebelum kegiatan belajar mengajar berlangsung.

Sunarto (2006) setiap individu pada hakekatnya akan mengalami pertumbuhan fisik dan perkembangan nonfisik yang meliputi aspek-aspek fisik, intelektual, emosi, sosial, dan psikomotor.

\section{Metode Pembelajaran Role Playing}

Metode (method), secara harfiah berarti cara. Selain itu metode atau metodik berasal dari bahasa Greeka, metha, (melalui atau melewati), dan hodos (jalan atau cara), jadi metode bisa berarti jalan atau cara yang harus di lalui untuk mencapai tujuan tertentu.

Oemar Hamalik (2010) mengatakan bahwa bermain peran atau sosiodrama adalah suatu jenis teknik simulasi yang umumnya digunakan untuk pendidikan sosial dan hubungan antarinsani. Ginnot (1961; dalam Eka, 2008) menegaskan bahwa Role Playing merupakan seperangkat prosedur yang digunakan untuk melakukan konseling dengan anak melalui penggunaan secara sistematis dari metode bermain, permainan, dan alat permainan. Sedangkan menurut Van 


\section{Didaktik : J urnal Pendidikan Guru Sekolah Dasar, ISSN : 2477-5673 \\ Sekolah Tinggi Keguruan dan IImu Pendidikan Subang \\ Volume I Nomor 2, J uli 2016}

Fleet (2001) menyatakan Role Playing merupakan intervensi yang dikembangkan yang berkaitan dengan penggunaan sistematis dari metode bermain oleh seorang konselor untuk membawa peningkatan dalam kemampuan peserta didik sampai penampilan yang optimal di sekolah.

Dari pendapat di atas dapat disimpulkan bahwa langkah-langkah metode role playing adalah sebagai berikut : 1) mempersiapkan masalah atau materi yang akan dibahas, 2) menjelaskan materi atau masalah yang akan dibahas, 3) mempersiapkan peserta didik yang akan menjadi pemeran, 4) menjelaskan kepada peserta didik lain tentang peran-peran yang akan dibawakan, 5) mendiskusikan terlebih dahulu tentang proses yang akan dilaksanakan, 6) bermain peran, 7) mendiskusikan hasil dari bermain peran, 8) mengkaji kemanfaatannya dalam kehidupan nyata melalui saling tukar pengalaman dan penarikan kesimpulan.

\section{METODE PENELITIAN}

Pada penelitian ini metode yang digunakan adalah metode Penelitian Tindakan Kelas (PTK). PTK merupakan suatu bentuk penelitian yang bersifat reflektif dengan melaksanakan tindakan dengan tujuan memperbaiki proses pembelajaran sehingga dapat meningkatkan kemampuan operasi penjumlahan bilangan bulat. Kemmis (1983) menyatakan bahwa penelitian tindakan merupakan upaya mengujicobakan ide-ide ke dalam praktik untuk memperbaiki atau mengubah sesuatu agar memperoleh dampak nyata dari situasi.

\section{HASIL PENELITIAN}

\section{Siklus I}

Ketercapaian proses pelaksanaan pembelajaran pada siklus I secara keseluruhan dapat dilihat pada diagram di bawah :

Diagram 1

Diagram Ketercapaian Proses

Pelaksanaan Pembelajaran Siklus I

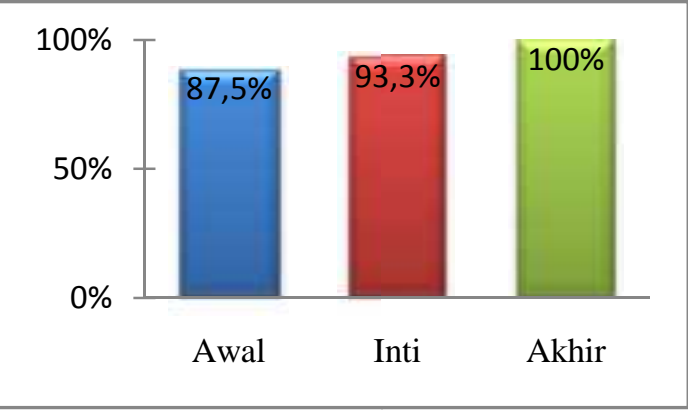

Sumber : hasil ketercapaian proses pelaksanaan pembelajaran di kelas $\mathrm{V}$

Berdasarkan diagram hasil analisis terhadap angket ketercapaian pemahaman konsep peserta didik di atas, maka peneliti menyimpulkan bahwa pencapaian nilai aspek afektif peserta didik secara individu terhadap kegiatan yang diamati pada penelitian siklus I ini sudah baik, namun masih ada peserta didik yang belum paham terhadap menghargai keragaman suku bangsa dan budaya. Pada penelitian siklus I ini diketahui bahwa peserta didik yang masuk dalam kategori BAIK sebanyak 18 orang atau $60 \%$, peserta didik yang mendapat nilai kategori SEDANG sebanyak 10 orang atau $33,3 \%$, dan peserta didik yang mendapat nilai kategori KURANG sebanyak 2 orang atau $6,7 \%$.

Diagram 2 


\section{Didaktik : J urnal Pendidikan Guru Sekolah Dasar, ISSN : 2477-5673 \\ Sekolah Tinggi Keguruan dan Ilmu Pendidikan Subang Volume I Nomor 2, J uli 2016}

Diagram Ketercapaian Proses

Pelaksanaan Pembelajaran Siklus II

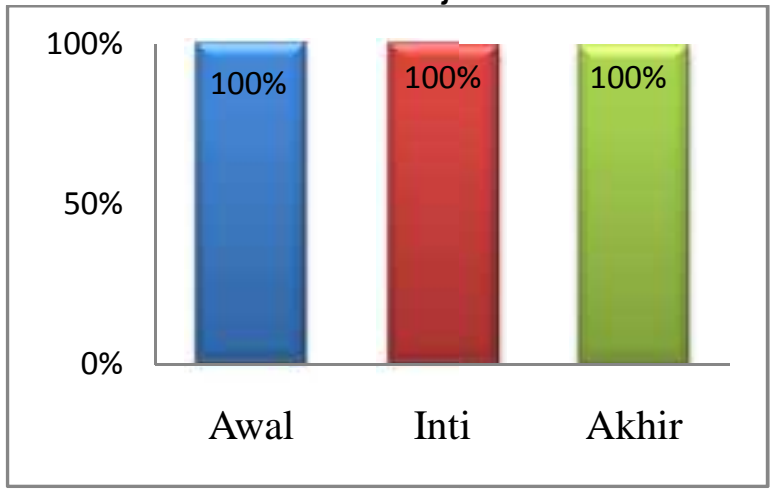

Sumber : hasil ketercapaian proses pelaksanaan pembelajaran di kelas $\mathrm{V}$

Berdasarkan hasil dari penelitian siklus II yang dibandingkan dengan indikator keberhasilan penelitian tindakan kelas yang telah ditentukan, maka dapat di lihat bahwa hasil penilaian rubrik RPP secara keseluruhan telah mencapai indikator keberhasilan. Hasil lembar observasi pelaksanaan pembelajaran secara keseluruhan juga telah mencapai indikator. Hasil post-tes ketercapaian peserta didik telah mencapai peningkatan dengan baik, karena dari 30 peserta didik terdapat 28 orang atau $93,3 \%$ peserta didik yang mendapat nilai kategori BAIK, maka target indikator keberhasilan telah mencapai > 85\%.

Hasil pemahaman konsep peserta didik melalui angket sebagian besar peserta didik sudah paham terhadap menghargai keragaman suku bangsa dan budaya, karena diketahui semua peserta didik yang masuk dalam kategori BAIK sebanyak 30 orang atau $100 \%$. Hasil pencapaian nilai aspek afektif peserta didik secara individu terhadap aspek-aspek dan kegiatan yang diamati pada penelitian siklus I ini meningkat secara baik, karena diketahui bahwa peserta didik yang masuk dalam kategori BAIK sebanyak 29 orang atau 96,7\%. Hasil pencapaian nilai aspek psikomotor peserta didik secara individu terhadap aspek-aspek dan kegiatan yang diamati pada penelitian siklus I ini meningkat secara signifikan, karena diketahui bahwa peserta didik yang masuk dalam kategori BAIK sebanyak 28 orang atau 93,3\%. Pada siklus II, ketiga aspek ini telah mencapai target indikator keberhasilan yakni > 85\%.

\section{PEMBAHASAN}

1. Perencanaan Pembelajaran dengan penerapan metode Role Playing pada pemahaman konsep keragaman suku bangsa dan budaya di Indonesia

Agar pembelajaran metode Role Playing dapat diimplementasikan dalam proses pembelajaran, maka lebih dalam perlu dibuat rancangan pembelajaran yang berisi strategi pembelajaran Role Playing tersebut. Penyusunan perangkat pembelajaran yang dilakukan adalah penyusunan RPP. Perencanaan yang matang dibutuhkan untuk menciptakan proses pembelajaran yang berkualitas baik. Setiap pendidik sebelum melaksanakan kewajibannya di kelas, wajib menyusun RPP secara lengkap dan sistematis agar pembelajaran berlangsung secara sistematis, terarah, menyenangkan, memotivasi peserta didik untuk berpartisipasi aktif, serta memberikan ruang yang cukup bagi kreativitas dan sesuai dengan bakat, minat, dan perkembangan fisik serta psikologi peserta didik. 


\section{Didaktik : J urnal Pendidikan Guru Sekolah Dasar, ISSN : 2477-5673 \\ Sekolah Tinggi Keguruan dan IImu Pendidikan Subang \\ Volume I Nomor 2, J uli 2016}

\section{Impelemtasi Pembelajaran IPS dengan penerapan metode Role Playing}

Pelaksanaan pembelajaran merupakan implementasi dari RPP yang telah disusun. Pelaksanaan pembelajaran pada umumnya meliputi kegiatan pendahuluan, kegiatan inti dan kegiatan penutup. Pada tahap ini serangkaian strategi dan skenario pembelajaran yang telah disusun berusaha untuk diimplementasikan oleh peneliti dengan sebaik mungkin agar tujuan yang diinginkan dapat tercapai secara cepat dan tepat. Implementasi pembelajaran yang dilakukan peneliti dari siklus I sampai dengan siklus II menggunakan metode Role Playing. Model pembelajaran ini mengoptimalkan peserta didik untuk terlibat secara aktif dalam diskusi kelompok sehingga terjalin interaksi antar peserta didik dan memudahkan peserta didik untuk memahami konsep menghargai keragaman suku bangsa dan budaya di Indonesia.

\section{KESIMPULAN}

Berdasarkan analisis dan pembahasan hasil metode Role Playing pada pembelajaran IPS kelas $\mathrm{V}$ SD, peneliti dapat mengambil kesimpulan sebagai berikut:

1. Penggunaan metode Role Playing telah dapat meningkatkan pemahaman konsep peserta didik terhadap menghargai keragaman suku bangsa dan budaya di Indonesia dengan pelaksanaan pembelajaran mencapai 2 siklus.

2. RPP yang dikembangkan dalam pembelajaran telah merujuk pada Permendiknas Nomor 41 Tahun 2007 tentang Standar Proses yang intinya berisi komponen :
Identitas Mata Pelajaran, Standar Kompetensi, Kompetensi Dasar, Indikator

Pencapaian

Kompetensi, Tujuan

Pembelajaran, Materi Ajar, Alokasi Waktu, Metode Pembelajaran, Kegiatan Pembelajaran (Kegiatan pendahuluan, Kegiatan inti, dan Kegiatan penutup), Penilaian Hasil Belajar, dan Sumber Belajar.

3. Penggunaan metode Role Playing dapat menciptakan suasana belajar aktif dan menyenangkan pada mata pelajaran IPS bagi peserta didik kelas V SD Negeri Cijati. Dengan menggunakan metode Role Playing telah menarik perhatian peserta didik karena peserta didik mengalami langsung apa yang dipelajari sehingga meningkatan pemahaman konsep peserta didik.

4. Penggunaan metode Role Playing pendidik tidak lagi mendominasi kegiatan pembelajaran tetapi hanya bertindak sebagai fasilitator dan motivator jika telah sesuai dengan langkah-langkah pembelajaran dalam metode Role Playing. Secara umum peserta didik memberikan respon yang positif terhadap penggunaan metode Role Playing.

\section{DAFTAR PUSTAKA}

Arikunto, S, Dkk. 2010. Penelitian Tindakan Kelas. Jakarta : Pt. Bumi Aksara.

Aunurrahman. 2011. Belajar Dan Pembelajaran. Bandung : Cv Alfabeta.

Bahri, Syaiful Djamarah. 1997. Guru Dan Anak Didik Dalam Interaksi 


\section{Didaktik : J urnal Pendidikan Guru Sekolah Dasar, ISSN : 2477-5673 \\ Sekolah Tinggi Keguruan dan IImu Pendidikan Subang Volume I Nomor 2, J uli 2016}

Edukatif Suatu Pendekatan

Teoritis Psikologis. Jakarta : PT

Rineka Cipta.

Dimyati \& Mudjiono. 1999. Belajar

Dan Pembelajaran. Jakarta : PT

Rineka Cipta.

Hanafiyah \& Cucu Suhana. 2009.

Konsep Strategi Pembelajaran.

Bandung : Refika Aditama..

li, Yulia Fitriani. (2009). Skripsi

"Penggunaan Metode Bermain

Peran (Role Playing) untuk

Meningkatkan Hasil Belajar

Siswa Sd Kelas lii Pada Topik

Kegiatan Jual Beli Dalam

Pembelajaran Ips". Bandung :

Universitas Pendidikan Indonesia

Press.

lif Khoiru. A Dan Sofan Amri. 2011. Mengembangkan

Pembelajaran Ips Terpadu. Jakarta : PT Prestasi

Pustakaraya.

Irman Nurmansah. (2012). Skripsi "Penggunaan Metode Role Playing Untuk Meningkatkan Hasil Belajar Siswa Pada Materi Perjuangan Para Tokoh Masa Penjajahan Jepang". Bandung : Universitas Pendidikan Indonesia Press.

Mulyasa, E. 2009. Praktik Penelitian Tindakan Kelas. Bandung : PT Remaja Rosdakarya.

Munadi, Yudhi. 2010. Media Pembelajaran (Sebuah Pendekatan Baru). Jakarta : Gaung Persada (Gp) Press.

Nana, Supriatna, Dkk. 2009. Pendidikan Ips Di Sd. Bandung : Upi Press.

Nana Sudjana \& Ibrahim. 2009. Penelitian Dan Penelitian Pendidikan. Bandung : Sinar Baru Algensindo.

Permana, Jaka. 2012. Kapita Selekta Ips Sd. Bandung : Fkip Unpas.
Rochiati. 2007. Metode Penelitian Tindakan Kelas. Bandung : PT Remaja Rosdakarya.

Roestiyah. 2008. Strategi Belajar Mengajar. Jakarta : Pt Rineka Cipta.

Sagala, Syaiful. 2010. Konsep Dan Makna Pembelajaran. Bandung : Alfabeta.

Sapriya, Dkk. 2006. Pembelajaran Dan Evaluasi Hasil Belajar Ips. Bandung : Upi Press.

Sapriya, Dkk. 2007. Konsep Dasar Ips. Bandung : Laboratorium Pkn UPI.

Sudjana, Nana. 2011. Dasar-Dasar Proses Belajar Mengajar. Sinar Bandung : Baru Algensindo.

Sukidin, Basrowi, Dan Suranto. 2010. Manajemen Penelitian Tindakan Kelas. Bandung : Insan Cendikia.

Sunarto Dan A. Hartono. 2006. Perkembangan Peserta Didik. Jaskarta : PT Rineka Cipta.

Suradisastra. D, Dkk. (1991/1992). Pendidikan Ips lii. Depdikbud. Direktorat Jendral Pendidikan Tinggi Proyek Pembinaan Tenaga Kependidikan.

Syamsuddin, Dan Vismaia. 2007. Metode Penelitian Pendidikan Bahasa.Bandung : $\quad$ PT. Remaja Rosdakarya.

Syaripudin, Tatang Dan Kurniasih. 2011. Pedagogik Teoritis Sistematis. Bandung : Percikan IImu.

Tati Heriati \& Aas Saraswati. 2007. Modul Profesi Keguruan. Bandung : Fkip Unpas.

Wahab, A. A. [Ed]. (2007). Metode Dan Model-Model Mengajar IImu Pengetahuan Sosial (Ips). Bandung : Cv Alfabeta.

2006. Panduan Kurikulum Tingkat Satuan Pendidikan 
(Ktsp) Sd/Mi. Bp Dharma

Bhakti:Jakarta.

. 2012. Uu Ri Nomor 20

Tahun 2004 Tentang Sistem

Pendidikan Nasional,

Peraturan Pemerintah Ri

Nomor 19 Tahun 2005

Tentang Standar Nasional

Pendidikan, Peraturan

Pemerintah Ri Nomor 47

Tahun 2008 Tentang Wajib

Belajar. Yogyakarta : $\mathrm{Pt}$

Laksana. 